\title{
A 60-year record of 129l in Taal Lake sediments (Philippines): Influence of human nuclear activities at low latitude region
}

\author{
Zhang, Luyuan; Hou, Xiaolin; Li, Hong-chun; Xu, Xiaomei
}

Published in:

Chemosphere

Link to article, DOI:

10.1016/j.chemosphere.2017.11.134

Publication date:

2017

Document Version

Peer reviewed version

Link back to DTU Orbit

Citation (APA):
Zhang, L., Hou, X., Li, H., \& Xu, X. (2017). A 60-year record of ${ }^{129}$ I in Taal Lake sediments (Philippines): Influence of human nuclear activities at low latitude region. Chemosphere, 193, 1149-1156.

https://doi.org/10.1016/j.chemosphere.2017.11.134

\section{General rights}

Copyright and moral rights for the publications made accessible in the public portal are retained by the authors and/or other copyright owners and it is a condition of accessing publications that users recognise and abide by the legal requirements associated with these rights.

- Users may download and print one copy of any publication from the public portal for the purpose of private study or research.

- You may not further distribute the material or use it for any profit-making activity or commercial gain

- You may freely distribute the URL identifying the publication in the public portal 


\section{Accepted Manuscript}

A 60-year record of ${ }^{129}$ I in Taal Lake sediments (Philippines): Influence of human nuclear activities at low latitude region

Luyuan Zhang, Xiaolin Hou, Hong-chun Li, Xiaomei Xu

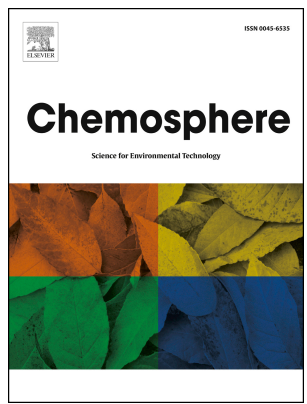

PII: S0045-6535(17)31911-2

DOI: 10.1016/j.chemosphere.2017.11.134

Reference: CHEM 20331

To appear in: ECSN

Received Date: 17 August 2017

Revised Date: 11 November 2017

Accepted Date: 22 November 2017

Please cite this article as: Zhang, L., Hou, X., Li, H.-C., Xu, X., A 60 -year record of ${ }^{129}$ I in Taal Lake sediments (Philippines): Influence of human nuclear activities at low latitude region, Chemosphere (2017), doi: 10.1016/j.chemosphere.2017.11.134.

This is a PDF file of an unedited manuscript that has been accepted for publication. As a service to our customers we are providing this early version of the manuscript. The manuscript will undergo copyediting, typesetting, and review of the resulting proof before it is published in its final form. Please note that during the production process errors may be discovered which could affect the content, and all legal disclaimers that apply to the journal pertain. 


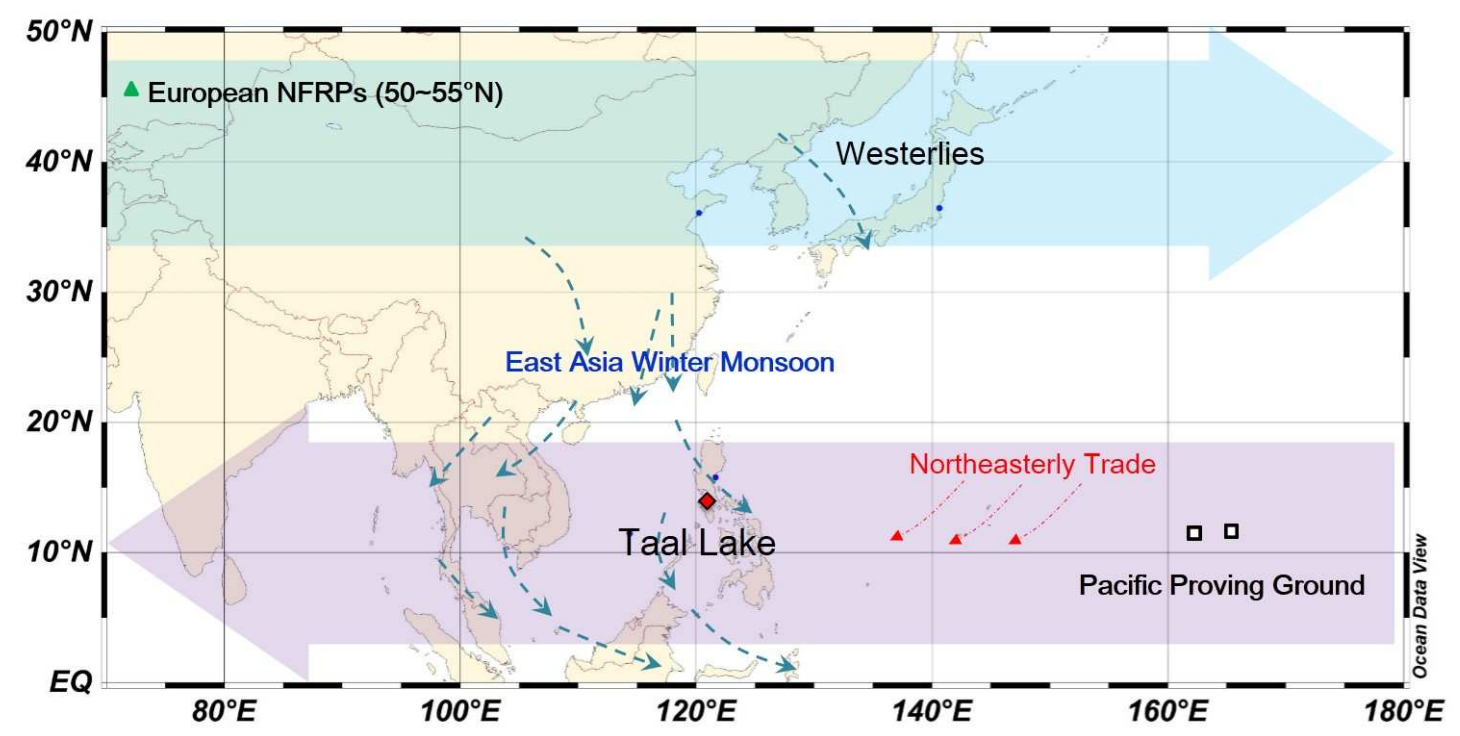


1

2

3

4

5

$6{ }^{1}$ State Key Laboratory of Loess and Quaternary Geology, Xi'an AMS Center,

7 Institute of Earth Environment, Chinese Academy of Sciences, Xi'an 710075,

8 China

$9 \quad{ }^{2}$ Center for Nuclear Technologies, Technical University of Denmark, Ris $\phi$

10 Campus, Roskilde 4000, Denmark

11

12

13

14

15

16

17

18

19 influence of human nuclear activities at low latitude region

Luyuan Zhang ${ }^{1}$, Xiaolin Hou ${ }^{1,2}{ }^{*}$, Hong-chun $\mathrm{Li}^{3}$, Xiaomei Xu ${ }^{4}$

3. Department of Geosciences, National Taiwan University, Taipei, Taiwan

4. Department of Earth System Science, University of California, Irvine, CA 92697, USA

*Author for correspondence.

E-mail: houxl@ieecas.cn; Tel: +86 29 62336192; Fax: +86 2962336199

Address: No.97 Yanxiang Road, Yanta district, Xi'an city, Shaanxi Province,

China

\section{A 60-year record of ${ }^{129} \mathrm{I}$ in Taal Lake sediments (Philippines):}


Abstract. The influence of human nuclear activities on environmental radioactivity is not well known at low latitude region that are distant from nuclear tests sites and nuclear facilities. A sediment core collected from Taal Lake in the central Philippines was analyzed for ${ }^{129} \mathrm{I}$ and ${ }^{127} \mathrm{I}$ to investigate this influence in a low-latitude terrestrial system. A baseline of ${ }^{129} \mathrm{I} /{ }^{127} \mathrm{I}$ atomic ratios was established at $(2.04-5.14) \times 10^{-12}$ in the pre-nuclear era in this region. Controlled by the northeasterly equatorial trade winds, increased ${ }^{129} \mathrm{I} /{ }^{127} \mathrm{I}$ ratios of $(20.1-69.3) \times 10^{-12}$ suggest that atmospheric nuclear weapons tests at the Pacific Proving Grounds in the central Pacific Ocean was the major source of ${ }^{129} \mathrm{I}$ in the sediment during $1956-1962$. The ${ }^{129} \mathrm{I} /{ }^{127} \mathrm{I}$ ratios, up to $157.5 \times 10^{-12}$ after 1964, indicate a strong influence by European nuclear fuel reprocessing plants. The East Asian Winter Monsoon is found to be the dominant driving force in the atmospheric dispersion of radioactive iodine $\left({ }^{129} \mathrm{I}\right)$ from the European nuclear fuel reprocessing plants to Southeast Asia, which is also important for dispersion of other airborne pollutants from the middle-high, to low latitude regions. A significant ${ }^{129} \mathrm{I} /{ }^{127} \mathrm{I}$ peak at $42.8 \mathrm{~cm}$ in the Taal Lake core appears to be the signal of the Chernobyl accident in 1986. In addition, volcanic activities are reflected in the iodine isotope profiles in the sediment core, suggesting the potential of using iodine isotopes as an indicator of volcanic eruptions. 
41 Keywords: Iodine-129 in sediment, Taal Lake, Human nuclear activities,

42 Northeasterly trade winds, East Asian Winter Monsoon, Indicator of volcanic

43 activity

44

45 
47 With the advent of the nuclear age, human nuclear activities (HNAs) mainly including nuclear weapons tests (NWTs), reprocessing of spent nuclear fuel, and the operation of nuclear power and research reactors, have produced a huge amount of radioactive materials. Only a small fraction of these radioactive substances have been released to the environment, but they can be found around

52 the globe. Among these radioactive substances, ${ }^{129}$ I, owing to its long half-life of $53 \quad 15.7$ million years, high fission yield $\left(0.706 \%\right.$ per fission of $\left.{ }^{235} \mathrm{U}\right)$ and volatility, serves as an excellent indicator of HNAs (Buraglio et al., 2001; Fehn and Snyder, 2000; Reithmeier et al., 2010). The global dispersion and distribution of ${ }^{129} \mathrm{I}$ in the environment are also a primary concern for its applications as a tracer for dispersion of gaseous pollutants, water masses movement and geochemical cycles of stable iodine in the atmosphere, hydrosphere and biosphere (Fehn, 2012; Hou et al., 2007; Zhang et al., 2016).

The global inventory of environmental ${ }^{129}$ I was about $6900 \mathrm{~kg}$ by 2009 (Hou et al., 2007). Naturally occurred ${ }^{129} \mathrm{I}$ was estimated to be at about $250 \mathrm{~kg}$, resulting 62 in a natural background ${ }^{129} \mathrm{I} /{ }^{127} \mathrm{I}$ atomic ratio of $\left(1.5 \times 10^{-12}\right)$ (Fehn et al., 2007)

63 in the marine system. Anthropogenic input has increased environmental ${ }^{129} \mathrm{I}$ levels by several orders of magnitude (Hou et al., 2009). Atmospheric NWTs

65 and nuclear accidents have released $50-150 \mathrm{~kg}$ and $7.2 \mathrm{~kg}{ }^{129} \mathrm{I}$, respectively 
66 (about $6 \mathrm{~kg}$ from the Chernobyl accident and $1.2 \mathrm{~kg}$ from the Fukushima

67 accident) (Hou et al., 2009; Hou et al., 2013; Hu and Moran, 2010). More than

$6895 \%$ of ${ }^{129} \mathrm{I}$ (about $5900 \mathrm{~kg}$ by 2009 ) in the environment was discharged by two

69 nuclear fuel reprocessing plants (NFRPs) at Sellafield (UK) and La Hague

70 (France) (Hou et al., 2007). In recent years, the marine discharge rate from the

71 two European NFRPs remains at a similar level as in 2009, approximately 200

$72 \mathrm{~kg} / \mathrm{yr}$, causing the global ${ }^{129} \mathrm{I}$ inventory of about $8300 \mathrm{~kg}$ by 2016 . Due to the 73 remarkable discharges of ${ }^{129} \mathrm{I}$ from the European NFRPs, ${ }^{129} \mathrm{I} /{ }^{127} \mathrm{I}$ ratios of up to $7410^{-6}$ have been reported in the European Seas (Alfimov et al., 2004; Hou et al., 2007; Yiou et al., 2002), six orders of magnitude higher than the natural background for ${ }^{129} \mathrm{I} /{ }^{127} \mathrm{I}$ ratio $\left(1.5 \times 10^{-12}\right)($ Fehn et al., 2007). In the regions far away from the HNA point sources, ${ }^{129} \mathrm{I} /{ }^{127} \mathrm{I}$ ratios have remained much lower, in the range of $(1-43.5) \times 10^{-10}$ in precipitation, river water, soil and vegetation in the USA and central China (Moran et al., 1999; Oktay et al., 2001; Zhang et al., 2011). Despite the reduced influence of HNAs, ${ }^{129} \mathrm{I} /{ }^{127} \mathrm{I}$ ratios in Antarctic surface seawater and snow $\left((0.06-9.5) \times 10^{-10}\right)$ were still more than 4 times higher than the natural background level $\left(1.5 \times 10^{-12}\right)$, indicating a predominant anthropogenic source of ${ }^{129} \mathrm{I}$ in the Antarctic environment (Xing et al., 2015).

Sediments are ideal archive for ${ }^{129}$ I time series records, which can provide useful information to evaluate influences from HNAs, and to understand environmental processes (Aldahan et al., 2007). Some marine and terrestrial sediment cores 
87 have been analyzed to explore the historic ${ }^{129}$ I records, either from NFRPs or

88 nuclear accidents (Englund et al., 2008; Gallagher et al., 2005; Oktay et al.,

89 2000; Santos et al., 2007). A recent study on ${ }^{129} \mathrm{I}$ in sediment from Jiaozhou Bay,

90 China showed five ${ }^{129} \mathrm{I} /{ }^{127} \mathrm{I}$ peaks, reflecting atmospheric NWTs at the Pacific

91 Proving Ground (PPG), global fallout of atmospheric NWTs, Chinese

92 atmospheric NWTs, the Chernobyl accident, and NFRPs-derived ${ }^{129}$ I transported

93 by the westerly wind (Fan et al., 2016). However, the investigations of ${ }^{129}$ I have

94 mainly focused on middle-high latitude areas of the Northern Hemisphere

95 (Englund et al., 2008; Gallagher et al., 2005; Oktay et al., 2000; Santos et al.,

96 2007). It is well known that hundreds of megatons of nuclear weapons were

97 detonated over the Pacific Ocean between the equator and the Tropic of Cancer

98 during 1948 - 1962 (Andrews et al., 2016). Evaluation of the impact of these

99 nuclear activities and knowledge of the distribution pattern of ${ }^{129} \mathrm{I}$ are lacking at

100 low latitudes (Reithmeier et al., 2010; Snyder et al., 2010). Only a few data of

$101{ }^{129} \mathrm{I}$ in low latitude region are available in marine system. Time series records of

$102{ }^{129} \mathrm{I}$ in corals collected in the South China Sea, Con Dao (Vietnam), Guam, and

103 Rabaul (Papua New Guinea) have been reported. These results revealed

104 bomb-produced ${ }^{129} \mathrm{I}$ carried primarily through surface ocean currents to the

105 investigated sites (Bautista et al., 2016; Chang et al., 2016). Currently, ${ }^{129} \mathrm{I}$

106 measurements in only corals and oceanographic samples in low-latitude region 
107 have been reported, there are no measurement of time series of ${ }^{129} \mathrm{I}$ in terrestrial 108 samples is reported.

109 This work aims to investigate temporal variations, sources and transportation 110 pathways of ${ }^{129} \mathrm{I}$ in the low latitude terrestrial environment, in order to 111 understand the influence of HNAs in the region. This is implemented by 112 analysis of a sediment core collected in Taal Lake, central Philippines. Since 113 Taal Lake is a volcanic lake, the potential application of iodine isotopes in 114 volcanic eruptions is also explored.

\section{- 2. Material and methods}

\section{$116 \quad 2.1$ Geological setting}

117 Taal Lake resides in the Taal Volcano system, located in the southwest portion 118 of Luzon Island, central Philippines $\left(14^{\circ} 00.1^{\prime} \mathrm{N}, 120^{\circ} 59.1^{\prime} \mathrm{E}\right)$ (Fig. 1 and Fig. S1).

119 The climate at the study site is monsoonal. The prevailing surface winds vary 120 seasonally. When the western North Pacific subtropical high begins to move 121 northeastward around mid-May, the Asian summer monsoon brings 122 southwesterly winds that propagate over the Philippines. Subsequently, the East 123 Asian winter monsoon is established around November and brings northeasterly 124 surface winds to the Philippines (Villafuerte et al., 2014). The trade winds are the prevailing northeasterly surface winds found in the Philippines, and in the tropics of the Northern Hemisphere. 
127 Taal Lake sediments are primarily sourced from the watersheds that cover about

$128350 \mathrm{~km}^{2}$ in the surrounding land area, and are affected by the eroding lake slope 129 and extruded tephra (Ramos, 2002).

130 Taal Volcano with 33 recorded eruptions is considered one of the most active 131 volcanic centers in the Philippines. The most recent period of activity lasted 132 from 1965 to 1977 with the area of activity concentrated in the vicinity of Mount 133 Tabaro (Global volcanism program; Moore et al., 1966; Philippine Institute of 134 Volcanology and Seismology).

\subsection{Sampling and core chronology}

136 A gravity core of $120 \mathrm{~cm}$ length was collected at a water depth of $15 \mathrm{~m}$ and 20 137 m away from Taal lake shoreline, central Philippines in November, 2007. The 138 core is mainly dark brown-black clay, containing shells and volcanic ash. The 139 chronology of the sediment core was established by $\Delta{ }^{14} \mathrm{C}$ values determined 140 from plant remains, and compared with an atmospheric $\Delta{ }^{14} \mathrm{C}$ bomb curve (dating 141 model in the supplementary information, Fig. S2 and S3). Ages fall within the 142 period 1947 - 2004 ( $\mathrm{Li}$ and $\mathrm{Xu}, 2008$; Hua et al., 2013). The sedimentation rate 143 was calculated to be $2.04 \pm 0.01 \mathrm{~cm} \mathrm{y}^{-1}$. Based on assumption of a constant 144 sedimentation rate and the sampling resolution of $2-3 \mathrm{~cm}$ for each subsample, 145 the age uncertainties for entire core might be up to 5 years.

\subsection{Determination of ${ }^{129} I$ and ${ }^{127} I$}


147 The sediment samples were sectioned into $2-3 \mathrm{~cm}$ intervals, freeze-dried, ground 148 and sieved through a 200 mesh sieve. Combustion followed by solvent 149 extraction was used to separate iodine from the sediments. The analytical 150 method has been reported in detail elsewhere (Hou et al., 2010; Zhang et al., 151 2011; Zhou et al., 2010). In brief, $2 \mathrm{~g}$ of sediment was weighed into a quartz 152 boat. $500 \mathrm{~Bq}$ of ${ }^{125} \mathrm{I}$ was spiked to the sample to monitor chemical yield. The 153 sample was combusted at $800{ }^{\circ} \mathrm{C}$ in a four-tube Pyrolyser ${ }^{\circledR}$ furnace in an 154 atmosphere of $\mathrm{O}_{2}$ and $\mathrm{N}_{2}$ to release iodine (Zhou et al., 2010). The released 155 iodine was trapped in a $0.5 \mathrm{M} \mathrm{NaOH}-0.02 \mathrm{M} \mathrm{NaHSO}_{3}$ solution. One $\mathrm{mL}$ of the 156 trap solution was used reserved for ${ }^{127} \mathrm{I}$ determination, $3 \mathrm{ml}$ of trap solution was 157 transferred to a counting tube and measured for 125I using a NaI gamma 158 detector for monitoring chemical yield of iodine. After measurement, the 159 solution was combined with the remaining trap solution and was used to 160 separate ${ }^{129}$ I by solvent extraction. The solution was transferred into a separatory 161 funnel and $0.5 \mathrm{mg}$ of ${ }^{127} \mathrm{I}$ carrier (Woodward Inc., USA) was added. $\mathrm{NaHSO}_{3}$ and $\mathrm{HNO}_{3}$ were added to reduce iodine to iodide, and then $\mathrm{NaNO}_{2}$ was used to oxidize iodide to $\mathrm{I}_{2}$ that was extracted to chloroform $\left(\mathrm{CHCl}_{3}\right)$ phase. After 164 discarding the water phase, the $\mathrm{I}_{2}$ in $\mathrm{CHCl}_{3}$ phase was back extracted to water 165 phase by reducing $\mathrm{I} 2$ to iodide by $\mathrm{NaHSO}_{3}$ solution. This procedure was repeated 166 as an additional purification step. $\mathrm{AgNO}_{3}$ was added to the back-extracted 167 aqueous solution and the iodide was precipitated as AgI. The AgI precipitate 
168

169

170

171

172

173

174

175

176

177

178

179

180

181

182 183 ratios in samples. The final results of ${ }^{129} \mathrm{I}$ were calculated by subtracting the 184 blank value.

was washed by $\mathrm{HNO}_{3}$ once, rinsed with deionized water twice, and dried at $60^{\circ} \mathrm{C}$ in an oven. The dried $\mathrm{AgI}$ precipitate was ground to fine powder and mixed with niobium powder (325 mesh, Alfa Aesar) in a mass ratio of 1:3, and pressed into a copper holder for AMS measurement.

The trap solutions were diluted ten-fold with $1 \% \mathrm{NH}_{3} \cdot \mathrm{H}_{2} \mathrm{O}$, and measured for stable iodine $\left({ }^{127} \mathrm{I}\right)$ using ICP-MS (X Series II ICP-MS, Thermal Electron Corporation). $\mathrm{Cs}^{+}$was added to the diluted solution as internal standard to a final concentration of $2 \mu \mathrm{g} / \mathrm{L}$. The detection limit of ${ }^{127} \mathrm{I}$ was calculated as 3 times SD of blanks to be $0.02 \mu \mathrm{g} / \mathrm{L}$.

${ }^{129}$ I was measured by a 3 MV Tandem AMS system (High Voltage Engineering Europa) at the Xi'an AMS center. $\mathrm{I}^{5+}$ ion was chosen for the measurements. Stable ${ }^{127} \mathrm{I}^{5+}$ currents were measured using a Faraday cup, and ${ }^{129} \mathrm{I}$ ions were measured using a gas ionization detector. All samples were measured for 6 cycles and 5 min per sample in each cycle. The procedural blanks are $1.5 \times 10^{-13}$ for ${ }^{129} \mathrm{I} /{ }^{127} \mathrm{I}$ ratios, which are more than 10 times lower than the measured ${ }^{129} \mathrm{I} /{ }^{127} \mathrm{I}$ 
187 Large variations of the concentrations of iodine isotopes were observed in the 188 sediment core (Fig. 2 and Table S1). The concentrations of ${ }^{127}$ I range from 2.97 $189 \mu \mathrm{g} / \mathrm{g}$ to $54.7 \mu \mathrm{g} / \mathrm{g}$ with a mean value of $(11.1 \pm 8.9) \mu \mathrm{g} / \mathrm{g}$. The maximum ${ }^{127} \mathrm{I}$ 190 concentration was observed at the depth of $7.1 \mathrm{~cm}$ (corresponding to the layer of 191 2002). ${ }^{129} \mathrm{I}$ concentrations range from $0.50 \times 10^{5}$ atoms $/ \mathrm{g}$ to $215.9 \times 10^{5} \mathrm{atoms} / \mathrm{g}$, 192 and in most samples, ${ }^{129} \mathrm{I}$ concentrations were lower than $84.7 \times 10^{5}$ atoms $/ \mathrm{g}$ 193 except for three samples at depths of $4.8-9.5 \mathrm{~cm}$. The ${ }^{129} \mathrm{I}$ peak was found at the 194 same subsurface layer as that of ${ }^{127} \mathrm{I}(7.1 \mathrm{~cm})$. Relatively lower ${ }^{129} \mathrm{I}$ and ${ }^{127} \mathrm{I}$ 195 concentrations, as compared to adjacent layers, were observed in two depths that 196 date to $1965-1970(73.2-77.0 \mathrm{~cm})$ and $1976-1977(57.7-59.7 \mathrm{~cm}) .{ }^{129} \mathrm{I} /{ }^{127} \mathrm{I}$ 197 ratios gradually increased from $2.04 \times 10^{-12}$ in $1952(109.5 \mathrm{~cm})$ to a peak value 198 of $157.4 \times 10^{-12}$ in $1984(42.8 \mathrm{~cm})$, then slightly decreased to $69.3 \times 10^{-12}$ in 1988 199 followed by a few minor fluctuations.

A significantly positive correlation was observed between ${ }^{129} \mathrm{I}$ and ${ }^{127} \mathrm{I}$ concentrations in the sediment ( $\mathrm{r}=0.81$ for the whole core) (Table S1), while no positive correlation or a weak correlation was reported in other sediment samples $(\mathrm{r}=0.15$ in the Jiaozhou Bay sediment, and $\mathrm{r}=0.29$ in the Kattegat sea 204 sediment) (Fan et al., 2016; López-Gutiérrez et al., 2004). Given the possible 205 influence of high values on correlation, elevated ${ }^{129} \mathrm{I}$ and ${ }^{127} \mathrm{I}$ concentrations 206 during 2000 - 2004 were excluded. No significant correlation could be observed 207 during 1948 - 1998 ( $\mathrm{r}=0.10)$. However, highly significant correlation was 
208 observed during $1964-1998(\mathrm{r}=0.93)$. Values of ${ }^{129} \mathrm{I}$ and ${ }^{127} \mathrm{I}$ during $1948-1954$

209 and 1956 - 1963 fell below the regression line of data during 1964 - 1998 (Fig.

210 S4). The environmental implication of the correlation are discussed below, in

211 the section 3.3.3.

\subsection{Level and variation of ${ }^{129} \mathrm{I} /{ }^{127} \mathrm{I}$ in Taal Lake sediment compared with}

\section{other sediment cores}

${ }^{127}$ I concentrations in Taal Lake sediment were comparable to those in coastal sediments from the Mississippi River Bight (3.4 - $34.3 \mu \mathrm{g} / \mathrm{g}$ ) and Chinese marginal seas (mean values of $14-22 \mu \mathrm{g} / \mathrm{g}$ ), but much lower than those in marine sediments from the Baltic Sea, Pacific and Arctic Ocean $(20-139 \mu \mathrm{g} / \mathrm{g})$

218 (Aldahan et al., 2007; Fan et al., 2016; Gao et al., 2003; Oktay et al., 2000). The 219 peak values of ${ }^{129} \mathrm{I}$ and ${ }^{127} \mathrm{I}$ concentrations occurred at a depth of $7.1 \mathrm{~cm}$ (in 220 2002). Similar patterns of ${ }^{129} I$ and ${ }^{127} I$ concentrations were reported for cores 221 from the Mississippi River and the Baltic Sea, in which ${ }^{129}$ I peaks occurred at 222 depths of $7-8 \mathrm{~cm}$ and $3-4 \mathrm{~cm}$, respectively (Aldahan et al., 2007; Oktay et al., 2000). Enrichment of iodine in subsurface sediment was attributed to anaerobic 224 degradation of organic matter in this layer, and re-adsorption of the released inorganic iodine to the subsurface layer (Aldahan et al., 2007; Price and Calvert, 
$227(87 \%)$ and abundant residual plants in this layer of the Taal Lake sediment core

228 (Table S1) (Li and $\mathrm{Xu}, 2008)$.

${ }^{129} \mathrm{I} /{ }^{127} \mathrm{I}$ ratios are distinctly different from ${ }^{129} \mathrm{I}$ and ${ }^{127} \mathrm{I}$ concentrations, and no 230 subsurface maximum was observed (Fig. 2). Long time series ${ }^{129} \mathrm{I}$ records in sediment cores have also been reported in other locations (Fan et al., 2016;

232 López-Gutiérrez et al., 2004; Oktay et al., 2000; Santos et al., 2007); and it is 233 generally agreed that ${ }^{129} \mathrm{I} /{ }^{127} \mathrm{I}$ ratios are more useful than ${ }^{129} \mathrm{I}$ concentrations, 234 when comparing ${ }^{129} \mathrm{I}$ levels in different sites and sample media. This is because 235 iodine concentrations in sediment cores vary significantly, and are generally 236 affected by environmental factors and sediment sources. Figure S5 compares the $237{ }^{129} \mathrm{I} /{ }^{127} \mathrm{I}$ ratios in sediment cores from marine and terrestrial systems. As expected, ${ }^{129} \mathrm{I} /{ }^{127} \mathrm{I}$ ratios in the Taal lake sediment fell well within those areas far away from HNAs, e.g., Jiaozhou Bay in China and the Mississippi River in USA 240 (Fan et al., 2016; Oktay et al., 2000). The ${ }^{129} \mathrm{I} /{ }^{127} \mathrm{I}$ ratios from Sweden, Ireland and Spain $\left(23.4 \times 10^{-12}\right.$ to $\left.7.69 \times 10^{-7}\right)$ are about $1-3$ orders of magnitude higher

242 than those from the low latitude lake and river sediments, doubtless due to the 243 direct influence of European NFRPs (Aldahan et al., 2007; Englund et al., 2008; 244 Gallagher et al., 2005; Santos et al., 2007). In contrast, marine sediments 245 collected from the Baltic Sea $\left(1.07 \times 10^{-8}\right.$ to $\left.7.50 \times 10^{-7}\right)$ and Kattegat Sea (3.69 $246 \times 10^{-10}$ to $2.77 \times 10^{-8}$ ) showed a similar range of ${ }^{129} \mathrm{I} /{ }^{127} \mathrm{I}$ ratios as lake sediments 247 from Central Sweden, both 3 - 5 orders of magnitude higher than that in Taal 
248 Lake. This is a quantitative indication that ${ }^{129} \mathrm{I} /{ }^{127} \mathrm{I}$ ratios in lake sediments are

249 mainly dependent on the proximity of HNAs and ${ }^{129}$ I transport pathways.

\subsection{Historic ${ }^{129}$ I records in low latitude terrestrial environment}

251 Characterized by a peak in the early 1960s followed by continuous decline, a

252 typical Northern Hemisphere bomb-produced $\Delta{ }^{14} \mathrm{C}$ signal was found in residual 253 plants extracted from Taal lake sediments (Fig. 3a, Li and Xu, 2008). Unlike $254 \Delta \Delta^{14} \mathrm{C}$, the variation of ${ }^{129} \mathrm{I} /{ }^{127} \mathrm{I}$ ratios in the sediment core is quite complicated, 255 due to variable ${ }^{129}$ I sources through time, including nature occurred, NWTs, 256 NFRPs and nuclear accidents releases over past decades. In order to clarify the 257 sources of ${ }^{129} \mathrm{I}$ and HNAs influence on low latitude regions, the 60 -year ${ }^{129} \mathrm{I}$ 258 record in the Taal lake core was divided into three periods, including the period 259 with consistently low ${ }^{129} \mathrm{I} /{ }^{127} \mathrm{I}$ ratios during 1948 - 1954, the first rise of ${ }^{129} \mathrm{I} /{ }^{127} \mathrm{I}$ 260 ratios during $1956-1980$, and the second rise leading up to 1984 and followed 261 by fluctuating ${ }^{129} \mathrm{I}^{127} \mathrm{I}$ ratios (Fig. 3a).

\subsubsection{A baseline of pre-nuclear ${ }^{129} \mathrm{I}^{127} \mathrm{I}$ ratios}

263 This period (1948 - 1954) features a platform of low ${ }^{129} \mathrm{I} /{ }^{127} \mathrm{I}$ ratios with an 264 average of $(3.66 \pm 1.14) \times 10^{-12}$, measured in the bottom layers $(105-120 \mathrm{~cm})$ of 265 the sediment core. The results are close to the natural marine background level 266 of ${ }^{129} \mathrm{I} /{ }^{127} \mathrm{I}$ ratio $\left((1.50 \pm 0.15) \times 10^{-12}\right)\left(\right.$ Fehn et al., 2007). This indicates that ${ }^{129} \mathrm{I}$ 267 in this period mainly originated from natural processes and that very limited 
268

269

270

271

272

273

274

275

276

277

278

279

280

281

282

283

284

285

286

287

288

vertical migration of iodine occurred in the sediment core. This is also supported by the pre-nuclear $\Delta^{14} \mathrm{C}$ values from $-26.8 \%$ o to $-40.3 \%$, at the same depths (Fig. $3 a)$.

The environmental background level cited above was derived by analyzing marine sediments from South Carolina and along the Western continental margin of the Americas (Fehn et al., 2007). As noted, ${ }^{129} \mathrm{I} /{ }^{127} \mathrm{I}$ ratios in 105-120 $\mathrm{cm}$ depth in the Taal Lake sediment core $\left((2-7-4.5) \times 10^{-12}\right)$ are slightly higher than the documented pre-nuclear ${ }^{129} \mathrm{I} /{ }^{127} \mathrm{I}$ value $\left(1.50 \times 10^{-12}\right)$ in the marine system. Tt is well known that stable ${ }^{127} \mathrm{I}$ concentrations in terrestrial surface waters (typically a few $\mu \mathrm{g} / \mathrm{L}$ ) are generally an order of magnitude lower than those of seawater $(40-60 \mu \mathrm{g} / \mathrm{L})$. If production rates of ${ }^{129} \mathrm{I}$ in the air are the same, this implies that the pre-nuclear ${ }^{129} \mathrm{I} /{ }^{127} \mathrm{I}$ ratios in Taal Lake should be an order of magnitude higher than $1.50 \times 10^{-12}$. Furthermore, addition of ${ }^{129} \mathrm{I}$ to the terrestrial sediment by spontaneous fission of ${ }^{238} \mathrm{U}$ in the crust could likewise raise the pre-nuclear ratio. That possibility is easily dismissed because the produced ${ }^{129} \mathrm{I}$ is only $0.22 \times 10^{5}$ atoms/g if assuming a maximum uranium concentration of $15 \mu \mathrm{g} / \mathrm{g}$ for calculation (Fabryka-Martin, 1988), which accounts for less than $15 \%$ of pre-anthropogenic ${ }^{129}$ I level in the Taal sediment. As shown in the Tinto river sediment (Spain), the naturally produced ${ }^{129} \mathrm{I} /{ }^{127} \mathrm{I}$ ratio was $2 \times 10^{-11}$, which is one order of magnitude higher than the pre-nuclear ${ }^{129} \mathrm{I} /{ }^{127} \mathrm{I}$ ratio (Santos et al., 2007). However, even though Taal Lake is terrestrial, it was reported that Taal Lake was 
289

290

291

292

293

294

295

296

297

298

299

300

301

302

303

304

305

306

307

connected with the sea by a navigational channel, while volcanic eruption in

1749 blocked the only channel and turned Taal Lake from marine environment to a brackish water reservoir (Ramos, 2002). This resulted in relatively high concentrations of ${ }^{127} \mathrm{I}$ in the lake sediment $(2.97-54.7 \mu \mathrm{g} / \mathrm{g})$, which were about one order of magnitude higher than those in Chinese stream sediments $(0.36$ $2.4 \mu \mathrm{g} / \mathrm{g}$ ) (Cheng et al., 2011). Therefore, the pre-nuclear Taal Lake ${ }^{129} \mathrm{I} /{ }^{127} \mathrm{I}$ ratios that are identical with those in marine sediment might be attributed to relatively high ${ }^{127}$ I concentrations due to the evolution of Taal Lake. In addition, it should be mentioned that the nuclear weapons tests in the PPG started from June 1946 until 1962. The fall out of the atmospheric tests in this site in 1946-1954 should be another reason causing slightly higher ${ }^{129} \mathrm{I} /{ }^{127} \mathrm{I}$ ratios in this period.

\subsubsection{Atmospheric NWT signal from the PPG through the northeasterly} trade winds

The ${ }^{129} \mathrm{I} /{ }^{127} \mathrm{I}$ ratios in the Taal Lake sediments increased by 10 - 50 times over the baseline values since 1956. The main feature of this period is a minima value in $1963\left(34.3 \times 10^{-12}\right)$ separating two peaks; the first one shows rapidly increased ${ }^{129} \mathrm{I} /{ }^{127} \mathrm{I}$ from $20.2 \times 10^{-12}$ in 1956 to $69.3 \times 10^{-12}$ in the early 1960 s, and the second is a quasi-constant ${ }^{129} \mathrm{I} /{ }^{127} \mathrm{I}$ peak of $(79.3-109) \times 10^{-12}$ during 1964 1980. 
308 The significantly increased ${ }^{129} \mathrm{I} /{ }^{127} \mathrm{I}$ ratios in the Taal Lake sediment core since

309 the mid-1950s indicate that the site received significant input of ${ }^{129}$ I produced by

310 atmospheric NWTs. At similar latitudes in the Northern Hemisphere $\left(11^{\circ} \mathrm{N}\right)$,

311104 aboveground NWTs were carried out in the PPG in the Marshall Islands

312 area during $1945-1962$, with a total yield of $152 \mathrm{Mt}$, which accounts for $34.6 \%$

313 of the total yield of worldwide atmospheric NWTs (440 Mt) (UNSCEAR, 2000).

314 Of these, 67 nuclear tests from July 1946 to August 1958 were conducted in the

315 Enewetak and Bikini Atolls (Department of Energy Nevada Operations Office,

316 2000), $4500 \mathrm{~km}$ and $4800 \mathrm{~km}$ east of Taal lake, respectively. There were no

317 NWTs at the PPG during 1959 - 1961. Due to a global atmospheric fallout lag to

318 the earth's surface of about 1 - 2 years (Hua et al., 2013) and dating uncertainty

319 of the core, the increased ${ }^{129} \mathrm{I} /{ }^{127} \mathrm{I}$ ratios in Taal Lake sediments during 1956 -

3201962 correspond to atmospheric NWTs before 1960. The apparent drop of

$321{ }^{129} \mathrm{I} /{ }^{127} \mathrm{I}$ ratio in the sediment core in 1963 (Fig. 3a) might correspond to the

322 no-tests period of 1959 - 1961. More atmospheric NWTs were conducted in

323 north of $30^{\circ} \mathrm{N}$ by the USA (Nevada, $37^{\circ} \mathrm{N}$ ), and Soviet Union (Semipalatinsk,

$32450^{\circ} \mathrm{N}$ and Novaya Zemlya, $73-74^{\circ} \mathrm{N}$ ). The total explosion yield at the PPG was

325 about four times higher than those north of $30^{\circ} \mathrm{N}$ during $1945-1958$, but five

326 times lower than the latter area during 1961 - 1962 (Fig. S6). Therefore,

327 atmospheric NWT at the PPG predominantly affected the study area before 3281958. 
329 The ${ }^{129} \mathrm{I} /{ }^{127} \mathrm{I}$ signals of atmospheric NWTs were also reported in the Jiaozhou

330 Bay sediment and Parola coral samples (Fig. 3b) (Bautista et al., 2016; Fan et al.,

331 2016). During 1956 - 1962, the peak value of the ${ }^{129} \mathrm{I} /{ }^{127} \mathrm{I}$ ratio in the Taal Lake

332 sediment is approximately five-fold higher than those reported in the Jiaozhou

333 Bay sediment and coral samples from Parola and Baler (Fig. 3b). The relatively

334 lower ${ }^{129} \mathrm{I} /{ }^{127} \mathrm{I}$ ratios in the marine system might be attributed to high ${ }^{127} \mathrm{I}$

335 concentrations in the ocean. It has been reported that close-in fallout around the

336 PPG could be carried by the North Pacific Equatorial current to the east coast of

337 Philippines and South China Sea as seen in coral ${ }^{129}$ I records from Con Dao and

338 Xisha Islands (Chang et al., 2016). Although the possible seawater intrusion into

339 the Taal Main Crater Lake (in Taal Volcano) (Delmelle et al., 1998) might carry

340 PPG-derived ${ }^{129} \mathrm{I}$ into Taal Lake, the relatively low ${ }^{129} \mathrm{I} /{ }^{127} \mathrm{I}$ ratios in the Baler

341 corals (equilibrium with ${ }^{129} \mathrm{I} /{ }^{127} \mathrm{I}$ in seawater) (Bautista et al., 2016) imply that

342 seawater intrusion was not the major source of ${ }^{129} \mathrm{I}$ in the Taal Lake sediment.

343 The high ${ }^{129} \mathrm{I} /{ }^{127} \mathrm{I}$ ratios in Taal Lake sediments were thus attributed to deposition

344 of airborne ${ }^{129} \mathrm{I}$ of atmospheric NWTs. Meteorological observations have shown

345 often brisk northeast trade winds at the PPG in the Marshall Islands. Radioactive

346 substances dispersed to the west as they fell through the trade winds (Kunkle

347 and Ristvet, 2013). Furthermore, the HASL aerial surveys have suggested that

348 radioactive contamination from the PPG was found in the islands of Yap

$349\left(9^{\circ} 32^{\prime} \mathrm{N}, 138^{\circ} 05^{\prime} \mathrm{E}\right)$ and Iwo Jima $\left(24^{\circ} 47^{\prime} \mathrm{N}, 141^{\circ} 20^{\prime} \mathrm{E}\right)$ in the west Pacific 
350 (Kunkle and Ristvet, 2013). This suggests that northeasterly trade winds play a

351 key role in transporting ${ }^{129}$ I from the PPG to Taal Lake, Philippines. Although

352 fallout of the atmospheric NWTs conducted north of $30^{\circ} \mathrm{N}$ also dispersed and

353 deposited iodine at low latitudes, the ${ }^{129} \mathrm{I} /{ }^{127} \mathrm{I}$ ratio in 1964 layer of the Taal Lake

354 sediment was only 1.5 times higher than that in 1960 , indicating that they were

355 minor contributors due to longer transportation distances.

356 With the signing of the Partial Test Ban Treaty in 1963, no further atmospheric

357 NWTs were conducted at the PPG. Since then, all the atmospheric NWTs were

358 conducted north of $35^{\circ} \mathrm{N}$ and the South Pacific region, including 26 tests in Lop

359 Nor, China during 1964 - 1980, and 46 tests in French Polynesia during 1966 -

3601974 (Fig. S6) (Norris, 1996; Ribbe and Tomczak, 2006). Unlike the Jiaozhou

361 Bay sediment core with two peaks during 1963 - 1980, rather constant ${ }^{129} \mathrm{~J}^{127} \mathrm{I}$

362 ratios of $(79-109) \times 10^{-12}$ were observed in the Taal Lake sediment core in

363 1964-1980, which are less than 1.4-fold higher than the peak in 1960. The

364 contribution of Chinese tests cannot be completely ruled out, but it is apparent

365 that these tests were not a major contributor to the low latitude area. This is

366 because 1) no peaks can be identified during 1963 - 1980, and 2) the total yield

367 of Chinese tests was very low compared to that conducted at the PPG. The

368 contribution from the French tests can be easily ruled out because all the tests

369 were conducted to the south of $21^{\circ} \mathrm{S}$, where ${ }^{129} \mathrm{I}$ is hardly carried to the north

370 hemisphere. The results are indicative of a uniform input of ${ }^{129} \mathrm{I}$ from the 
371 middle-high latitude regions. European NFRPs started to release gaseous ${ }^{129}$ I to

372 the atmosphere from the early 1950s, and reached about $100 \mathrm{GBq} / \mathrm{y}$ in the $1960 \mathrm{~s}$

373 (Fig. 3c) (Bautista et al., 2016; Reithmeier et al., 2010), which is about 10 - 100

374 times higher than the total ${ }^{129}$ I released from all atmospheric NWTs after 1963

375 (Fig. 3c). Thus, the addition of airborne ${ }^{129}$ I originated from the NFRPs became

376 the major source of ${ }^{129}$ I during 1964 - 1980, indicating the influence of NFRPs

377 on low latitude region.

378 3.3.3 Nuclear facilities-released ${ }^{129}$ I after 1980: influence of the East Asian

379 Winter Monsoon

380 It is notable that ${ }^{129} \mathrm{I} /{ }^{127} \mathrm{I}$ ratios in the Taal Lake sediment rapidly increased after 3811980 , reaching a maximum value $\left(157.5 \times 10^{-12}\right)$ for the whole core in 1984 , and 382 followed by four small peaks in $\sim 1989, \sim 1995, \sim 1997$ and $\sim 2004$ (Fig. 3a). No 383 atmospheric NWTs has occurred after 1980, whereas the total airborne ${ }^{129} \mathrm{I}$ 384 released from the NFRPs in Europe, Former Soviet and United States greatly 385 increased to a maximum value of $200 \mathrm{GBq} / \mathrm{y}$ in 1984 (Bautista et al., 2016; 386 Reithmeier et al., 2010). The rapid increase in ${ }^{129} \mathrm{I} /{ }^{127} \mathrm{I}$ ratios in Taal Lake during $387 \quad 1980-1984$ could be attributed to gaseous releases of ${ }^{129}$ I from the European 388 NFRPs (Fig. 3c). Since 1996, atmospheric releases of ${ }^{129}$ I from the two major 389 NFRPs at Sellafield and La Hague dramatically decreased to about $30 \mathrm{GBq} / \mathrm{y}$ 390 (Bautista et al., 2016), while liquid discharge of ${ }^{129} \mathrm{I}$ from the two NFRPs into the 
391

392

393

394

395

396

397

398

399

400

401

402

403

404

405

406

407

408

409

410

sea significantly increased from $20 \mathrm{GBq} / \mathrm{y}$ in the 1950 s to around $2200 \mathrm{GBq} / \mathrm{y}$ $(350 \mathrm{~kg} / \mathrm{y})$ in the 2000s (Hou et al., 2007). Studies on ${ }^{129} \mathrm{I}$ in aerosols and rainwater have shown that re-emission of ${ }^{129} \mathrm{I}$ from contaminated seawater has become a key contributor to ${ }^{129} \mathrm{I}$ in the atmosphere (Englund et al., 2010; Reithmeier et al., 2006; Zhang et al., 2016). It can be estimated that the amount of re-emitted ${ }^{129}$ I from the sea to the atmosphere has increased to $90 \mathrm{GBq} / \mathrm{y}(13.8$ $\mathrm{kg} / \mathrm{y}$ ) in the 2000s (Fig. 3c), assuming a $0.3 \%$ annual re-emission rate of the total ${ }^{129}$ I inventory in the upper layer of the ocean (Reithmeier et al., 2006). This implies that re-emission of liquid discharged ${ }^{129}$ I from the NFRPs become the major ${ }^{129}$ I source to Taal Lake sediments after 1996, instead of direct gaseous releases.

The ${ }^{129}$ I pulse from the Chernobyl nuclear accident occurred in 1986 had been widely observed in sediment cores and in corals (Bautista et al., 2016; Fan et al., 2016; Hou et al., 2003). However, the maximum ${ }^{129} \mathrm{I} /{ }^{127} \mathrm{I}$ ratio in the sediment core in this study was dated to 1984 , this might be attributed to the uncertainty of the dating method and the contribution of other sources. The dating uncertainty due to the application of a uniform sedimentary rate of $2.04 \mathrm{~cm} / \mathrm{y}$ for the core chronology can explain this discrepancy. In particular, we expect a fast sedimentary rate during rapid deposition of volcanic ash and tephra during volcanic eruptions (Moore et al., 1966). Hence, the peak ${ }^{129} \mathrm{I} /{ }^{127} \mathrm{I}$ ratios that we 
411 observe around 1984 likely reflect an integrated signal of airborne

412 NFRPs-derived ${ }^{129}$ I with the Chernobyl signal.

413 After the 1984 peak value, ${ }^{129} \mathrm{I} /{ }^{127} \mathrm{I}$ ratios in the sediment core declined 414 significantly. Three small ${ }^{129} \mathrm{~J}^{127} \mathrm{I}$ peaks (Fig. 3a), in 1989, 1995, 1997 were 415 observed, which are correspond well to the releases of ${ }^{129}$ I from the two European 416 NFRPs in 1989, 1994 and 1996 (Fig. 3c). These peaks were not observed in the 417 coral sample from Parola, Philippines, likely because the coral signals have been 418 smoothed by dilution of high level ${ }^{127} \mathrm{I}$ in seawater. The difference in ${ }^{129} \mathrm{I}$ records 419 between the Taal Lake sediment and Parola coral suggests that terrestrial 420 sediments may provide more sensitive ${ }^{129}$ I information than marine archives. As 421 discussed above, air transport is the primary pathway that carries iodine to low 422 latitude region. However, in spite of higher seawater ${ }^{127}$ I concentrations and 423 subsequent dilution, the ${ }^{129} \mathrm{I} /{ }^{127} \mathrm{I}$ values in Jiaozhou Bay sediments are still 424 higher than those of Taal Lake after 1990 (Fig. 3b). This difference is attributed 425 to the prevailing winds that affect each site. Jiaozhou Bay is located in 426 mid-latitude region $\left(39^{\circ} \mathrm{N}\right)$, and exactly in the pathway of the westerlies, which 427 is known to carry re-emitted ${ }^{129}$ I from European seas (Fan et al., 2016) to east 428 direction. The Tall Lake $\left(14^{\circ} \mathrm{N}\right)$ is not directly affected by the westerlies which 429 extend only to about $30^{\circ} \mathrm{N}$. Whereas the westerlies with an enriched ${ }^{129} \mathrm{I}$ air mass 430 pass over the west Pacific are relatively depleted in ${ }^{129} \mathrm{I}$. Toyama et al. (2013) 431 has showed relatively low ${ }^{129} \mathrm{I} /{ }^{127} \mathrm{I}$ ratios in atmospheric samples (precipitation 
432 containing airborne particulate dust) from Ishigaki Island $\left(24^{\circ} 20^{\prime} \mathrm{N}, 124^{\circ} 9^{\prime} \mathrm{E}\right)$, 433 approximately $1200 \mathrm{~km}$ northeast of Taal Lake. Due to the monsoonal climate in 434 the Philippines, the sampling site is variably affected by ${ }^{129}$ I-enriched East Asian 435 winter monsoon and ${ }^{129}$ I-poor air during East Asian summer monsoon (An et al., 436 2015; Loo et al., 2015; Villafuerte et al., 2014) (Fig. 1). There is evidence that 437 eolian dust input related to the East Asian winter monsoon is the main 438 provenance of sediments in the Philippine Sea (Xu et al., 2013). Therefore, the 439 influence of European NFRPs on Taal Lake, Philippines is modulated by the 440 summer and winter East Asian monsoon. Although the East Asian winter 441 monsoon brings ${ }^{129}$ I from the mid-high latitude regions into Taal Lake, the direct 442 contribution of European NFRPs at this low latitude is lower than in the 443 mid-latitude regions of the North Hemisphere.

444 In the surface layer of the Taal Lake sediment core, the fourth ${ }^{129} \mathrm{I} /{ }^{127} \mathrm{I}$ peak in 445 2004 (Fig. 3a) might be related to an enhanced East Asian winter monsoon with 446 a high intensity index of 0.40 (relative to weak East Asian winter monsoon in $4472000-2003$ with a low average intensity index of -0.39) (He and Wang, 2012) 448 that carried more re-emitted ${ }^{129}$ I from European seas (the $4^{\prime}$ peak in Fig. 3c) to 449 the low latitude region. More study is needed to further confirm this assumption.

450 It is worth noting the significant positive correlation between ${ }^{129} \mathrm{I}$ and ${ }^{127} \mathrm{I}$ during $451 \quad 1964-1998$ (the period with increased ${ }^{129}$ I signal mainly from the European 
452 NFRPs) (Fig. S4), indicating that both ${ }^{129} \mathrm{I}$ and ${ }^{127} \mathrm{I}$ in Taal Lake sediments were

453 mainly transported by the East Asian winter monsoon (Xu et al., 2013). While 454 no correlation between ${ }^{129} \mathrm{I}$ and ${ }^{127} \mathrm{I}$ during 1956 - 1963 reflected that the two 455 isotopes were from different air masses, ${ }^{129}$ I controlled by the northeasterly trade 456 and ${ }^{127} \mathrm{I}$ by the East Asian winter monsoon in that period.

457 Other nuclear activities might also contribute ${ }^{129}$ I to Taal Lake. As of 2004, 68 458 nuclear power reactors were in operation in Japan, South Korea and China 459 adjacent to the Philippines, with a net capacity of 60,519 MWe (Table S2) 460 (World Nuclear Association, 2017). ${ }^{129}$ I generated by nuclear power production 461 was stored in the spent fuel. Our previous determinations of ${ }^{129} \mathrm{I} /{ }^{127} \mathrm{I}$ ratios in 462 surface seawater in the vicinity of Chinese NPPs did not show a significant 463 ${ }^{129} \mathrm{I} /{ }^{127} \mathrm{I}$ gradient in seawater samples collected from locations with a distance to the outlet of $2-7 \mathrm{~km}$, and all at background level in this region (He et al., 2011; Zhang et al., 2012), indicating no measurable contribution to the environmental ${ }^{129}$ I from these NPPs. A NFRP located in Tokai, Japan has released about $1.0 \mathrm{~kg}$ $467{ }^{129} \mathrm{I}$ since its operation from 1977 until 2005, which results in a maximum ${ }^{129} \mathrm{I}$ 468 release of $0.15 \mathrm{~kg} / \mathrm{y}$ in 1985 (JAEA, 2006; Shinohara, 2004), less than $10 \%$ of ${ }^{129}$ I re-emitted from NFRPs-influenced oceans (1.5 - $\left.13.8 \mathrm{~kg} / \mathrm{y}\right)$ during 1980 $4702004 .{ }^{129} \mathrm{I} /{ }^{127} \mathrm{I}$ ratios of $(40-80) \times 10^{-12}$ in surface seawater collected from Japan 471 Basin, Yamato Basin and offshore of Kushiro in 2007 were reported (Suzuki et 472 al., 2010), showing an insignificant contribution of the Japanese nuclear 
473 reprocessing plant on ${ }^{129} \mathrm{I}$ in the Taal Lake. Therefore, the contribution of ${ }^{129} \mathrm{I}$

474 from the adjacent NPPs and the Tokai NFRP is considered negligible in the Taal

475 Lake sediment record.

\subsection{Relation of volcanic activities with iodine isotopes}

477 Relatively lower concentrations of ${ }^{127} \mathrm{I}$ (about $\left.5 \mu \mathrm{g} / \mathrm{g}\right)$ and ${ }^{129} \mathrm{I}\left(<29.4 \times 10^{5}\right.$ 478 atoms/g) were observed in the sediment samples during 1965 - 1977. These 479 decreases in ${ }^{127} \mathrm{I}$ and ${ }^{129} \mathrm{I}$ concentrations well correspond to the Taal volcanic 480 eruptions (Fig. 2). Microscope observation of the sediment showed that these 481 layers contained high amount of volcanic glass, but less water (55\%), organic 482 matters and carbonates ( $\mathrm{Li}$ and $\mathrm{Xu}, 2008$ ) (Table S1), confirming the 483 contribution of the volcanic sources. Due to mixing of iodine-free volcanic 484 materials (iodine has evaporated in high temperature during volcanic eruption), 485 iodine concentrations can be potentially used to record historic volcanic 486 activities.

\section{- 4. Conclusions and perspectives}

488 Distribution of ${ }^{129} \mathrm{I}$ and ${ }^{127} \mathrm{I}$ in a sediment core collected in Taal Lake, 489 Philippines shows three distinct ${ }^{129} \mathrm{I}$ depositional periods: (1) pre-nuclear ${ }^{129} \mathrm{I}$, 490 providing a baseline to evaluate the influence of HNAs; (2) atmospheric 491 NWTs-originated ${ }^{129} \mathrm{I}$, showing a strong influence from the atmospheric NWTs 492 at the PPG through the northeasterly trade; (3) NFRPs-derived ${ }^{129}$ I, featuring by 
493 high resolution ${ }^{129}$ I records of direct gaseous releases and secondary emission of

$494{ }^{129}$ I from oceans contaminated by liquid discharge of NFRPs. It was also found 495 that East Asian winter monsoon plays a significant role in the transport of ${ }^{129} \mathrm{I}$ 496 and influence of European NFRPs at the study site. It could also transport other 497 volatile gaseous pollutants from mid- to low-latitude areas. In addition, this 498 work suggests that iodine isotopes have potential to trace volcanic activities.

\section{- Acknowledgement}

500 This work was supported by Natural Science Foundation of China (No. 501 11605207), Ministry of Science and Technology of China (No. 2015FY110800), and State Key Laboratory of Loess and Quaternary Geology. Financial support 503 from the Ministry of Science and Technology of Taiwan (MOST) to H.-C. Li is NSC97-2628-M-006-014. All the staff for sample collection are sincerely 505 grateful. We acknowledge Dr. George Burr and anonymous referees for their 506 constructive comments and language improvement.

\section{Additional Information}

509 Supplementary information of this paper can be found in at 510 http://dx.doi.org/10.106/J.chemosphere.

511 Competing interests: The authors declare no competing interests. 
513

514

515

516

517

518

519

520

521

522

523

524

525

526

527

528

529

530

531

532

\section{- References}

Aldahan, A., Englund, E., Possnert, G., Cato, I., Hou, X., 2007. Iodine-129 enrichment in sediment of the Baltic Sea. Appl. Geochem. 22, 637-647.

Alfimov, V., Aldahan, A., Possnert, G., Kekli, A., Meili, M., 2004. Concentrations of ${ }^{129}$ I along a transect from the North Atlantic to the Baltic Sea. Nucl. Instrum. Meth. B 223-224, 446-450.

An, Z., Wu, G., Li, J., Sun, Y., Liu, Y., Zhou, W., Cai, Y., Duan, A., Li, L., Mao, J., Cheng, H., Shi, Z., Tan, L., Yan, H., Ao, H., Chang, H., Feng, J., 2015. Global Monsoon Dynamics and Climate Change. Annu. Rev. Earth Planet. Sci. 43, 29-77.

Andrews, A.H., Asami, R., Iryu, Y., Kobayashi, D.R., Camacho, F., 2016. Bomb-produced radiocarbon in the western tropical Pacific Ocean: Guam coral reveals operation-specific signals from the Pacific Proving Grounds. J. Geophys. Res. Ocean. 121, 6351-6366.

Bautista, A.T., Matsuzaki, H., Siringan, F.P., 2016. Historical record of nuclear activities from ${ }^{129} \mathrm{I}$ in corals from the northern hemisphere (Philippines). J. Environ. Radioactiv. 164, 174-181.

Buraglio, N., Aldahan, A., Possnert, G., 2001. ${ }^{129}$ I in lakes of the Chernobyl fallout region and its environmental implications. Appl. Radial. Isot. 55, $715-720$. 
533 Chang, C.C., Burr, G.S., Jull, A.J.T., Russell, J.L., Biddulph, D., White, L.,

534 Prouty, N.G., Chen, Y.G., Shen, C.C., Zhou, W., Lam, D.D., 2016.

535 Reconstructing surface ocean circulation with ${ }^{129} \mathrm{I}$ time series records from

536 corals. J. Environ. Radioactiv. 165, 144-150.

537 Cheng, Z., Liu, M., Zhang, Q., Gu, T., Huang, H., 2011. Preparation of 538 Geochemical Reference Materials of Stream Sediment. Rock Miner. Anal. 3, 539 $714-722$.

540 Delmelle, P., Kusakabe, M., Bernard, A., Fischer, T., de Brouwer, S., del 541 Mundo, E., 1998. Geochemical and isotopic evidence for seawater 542 contamination of the hydrothermal system of Taal Volcano, Luzon, the Philippines. Bull. Volcanol. 59, 562-576.

Department of Energy Nevada Operations Office, U.S., 2000. United States Nuclear Tests, July 1945 through September 1992, DOE/NV--209--REV15.

546 Englund, E., Aldahan, A., Hou, X., Possnert, G., Soderstrom, C., 2010. Iodine (I-129 and I-127) in aerosols from northern Europe. Nucl. Instrum. Meth. B 268, 1139-1141.

Englund, E., Aldahan, A., Possnert, G., 2008. Tracing anthropogenic nuclear activity with ${ }^{129}$ I in lake sediment. J. Environ. Radioactiv. 99, 219-229.

551 Fabryka-Martin, J., 1988. Production of radionuclides in the earth and their hydrogeologic significance, with emphasis on chlorine-36 and iodine-129. 
$\mathrm{PhD}$ thesis. Department of hydrology and water resources, The University of Arizona.

555 Fan, Y., Hou, X., Zhou, W., Liu, G., 2016. I record of nuclear activities in marine sediment core from Jiaozhou Bay in China. J. Environ. Radioactiv. $154,15-24$.

558 Fehn, U., 2012. Tracing crustal fluids: Applications of natural ${ }^{129} \mathrm{I}$ and ${ }^{36} \mathrm{Cl}$. Annu. Rev. Earth Planet. Sci. 40, 45-67.

560 Fehn, U., Moran, J.E., Snyder, G.T., Muramatsu, Y., 2007. The initial ${ }^{129}$ I/I ratio and the presence of "old" iodine in continental margins. Nucl. Instrum. Meth. B 259, 496-502.

563 Fehn, U., Snyder, G., 2000. ${ }^{129}$ I in the Southern Hemisphere: Global redistribution of an anthropogenic isotope. Nucl. Instrum. Meth. B 172, $366-371$.

Gallagher, D., McGee, E.J., Mitchell, P.I., Alfimov, V., Aldahan, A., Possnert,

Gao, A.G., Liu, Y.G., Zhang, D.J., Sun, H.Q., 2003. Latitudinal distribution of iodine in sediments in the Chukchi Sea and the Bering Sea. Sci. China Ser. D-Earth Sci. 46, 592-602.

573 Global volcanism program. http://www.volcano.si.edu. 
574 He, C., Hou, X., Zhao, Y., Wang, Z., Li, H., Chen, N., Liu, Q., Zhang, L., Luo,

575 M., Liang, W., Fan, Y., Zhao, X.L., 2011. ${ }^{129}$ I level in seawater near a 576 nuclear power plant determined by accelerator mass spectrometer. Nucl. Instrum. Meth. A 632, 152-156.

578 He, S., Wang, H., 2012. An integrated East Asia winter monsoon index and its 579 interannual vability. Chinese J. Atmos. Sci. (in Chinese) 36, 523-538.

580

581

582

583

584

585

586

587

588

589

590

591

592

593

Hou, X., Aldahan, A., Nielsen, S.P., Possnert, G., Nies, H., Hedfors, J., 2007. Speciation of I-129 and I-127 in seawater and implications for sources and transport pathways in the North Sea. Environ. Sci. Technol. 41, 5993-5999.

Hou, X., Fogh, C.L., Kucera, J., Andersson, K.G., Dahlgaard, H., Nielsen, S.P., 2003. Iodine-129 and Caesium-137 in Chernobyl contaminated soil and their chemical fractionation. Sci. Total Environ. 308, 97-109.

Hou, X., Hansen, V., Aldahan, A., Possnert, G., Lind, O.C., Lujanienė, G., 2009. A review on speciation of iodine-129 in the environmental and biological samples. Anal. Chim. Acta 632, 181-196.

Hou, X., Povinec, P.P.P., Zhang, L., Shi, K., Biddulph, D., Chang, C.-C.C.-C., Fan, Y., Golser, R., Hou, Y., Ješkovský, M., Jull, A.J.T., Liu, Q., Luo, M., Steier, P., Zhou, W.J., Hou, Y., Golser, R., 2013. Iodine-129 in Seawater Offshore Fukushima: Distribution, Inorganic Speciation, Sources, and Budget. Environ. Sci. Technol. 47, 3091-3098. 
594 Hou, X., Zhou, W.J., Chen, N., Zhang, L., Liu, Q., Luo, M., Fan, Y., Liang, W., 595 Fu, Y., 2010. Determination of ultralow level ${ }^{129} \mathrm{I} /{ }^{127} \mathrm{I}$ in natural samples by 596 separation of microgram carrier free iodine and accelerator mass spectrometry detection. Anal. Chem. 82, 7713-7721.

598 Hu, Q., Moran, J.E., 2010. Iodine, in: Atwood, D.A. (Ed.), Radionuclides in the 599 Environment. Wiley, West Sussex, United Kingdom.

$600 \mathrm{Hu}$, Q., Weng, J.Q., Wang, J.S., 2010. Sources of anthropogenic radionuclides 601 in the environment: a review. J. Environ. Radioactiv. 101, 426-437.

602

603

604

605

606

607

608

609

610

611

612

613

614

Hua, Q., Barbetti, M., Rakowski, A.Z., 2013. Atmospheric radiocarbon for the period 1950-2010. Radiocarbon 55, 1-14.

JAEA, 2006. Annual report on the effluent control of low level liquid waste in nuclear fuel cycle engineering laboratories FY 2005. http://jolissrch-inter.tokaisc. jaea.go.jp/pdfdata/JAEA-Review-2006-024.pdf.

Kunkle, T., Ristvet, B., 2013. Castle Bravo: Fifty years of legend and Lore-A guide to off-site radiation exposures, Special report. DTRIAC SR-12-001.

Li, H., Xu, X., 2008. Dating Taal Lake sediment of Philippines by using the bomb radiocarbon curve. Am. Geophys. Union, Fall Meet. 2008, Abstr. \#PP23A-1466.

Loo, Y.Y., Billa, L., Singh, A., 2015. Effect of climate change on seasonal monsoon in Asia and its impact on the variability of monsoon rainfall in Southeast Asia. Geosci. Front. 6, 817-823. 
615

616

617

618

619

620

621

622

623

624

625

626

627

628

629

630

631

632

633

634

635

López-Gutiérrez, J.M., García-León, M., García-Tenorio, R., Schnabel, C., Suter, M., Synal, H.A., Szidat, S., 2000. ${ }^{129} \mathrm{I} /{ }^{127} \mathrm{I}$ ratios and ${ }^{129} \mathrm{I}$ concentrations in a recent sea sediment core and in rainwater from Sevilla (Spain) by AMS. Nucl. Instrum. Meth. B 172, 574-578.

López-Gutiérrez, J.M., García-León, M., Schnabel, C., Suter, M., Synal, H.A., Szidat, S., García-Tenorio, R., 2004. Relative influence of ${ }^{129}$ I sources in a sediment core from the Kattegat area. Sci. Total Environ. 323, 195-210.

Moore, J.G., Nakamura, K., Alcaraz, A., 1966. The 1965 eruption of Taal Volcano, Philippines. Bull. Volcano. 29, 75-76.

Moran, J.E., Oktay, S.D., Santschi, P.H., Schink, D.R., 1999. Atmospheric dispersal of ${ }^{129}$ iodine from nuclear fuel reprocessing facilities. Environ. Sci. Technol. 33, 2536-2542.

Norris, R.S., 1996. French and Chinese Nuclear Weapon Testing. Secur. Dialogue 27.

Oktay, S.D., Santschi, P.H., Moran, J.E., Sharma, P., 2001. ${ }^{129}$ I and ${ }^{127}$ I transport in the Mississippi River. Environ. Sci. Technol. 35, 4470-4476.

Oktay, S.D., Santschi, P.H., Moran, J.E., Sharma, P., 2000. The ${ }^{129}$ iodine bomb pulse recorded in Mississippi River Delta sediments: results from isotopes of I, Pu, Cs, Pb, and C. Geochim. Cosmochim. Acta 64, 989-996.

Philippine Institute of Volcanology and Seismology, n.d. PHIVOLCS. URL http://www.phivolcs.dost.gov.ph/ 
636 Price, N.B., Calvert, S.E., 1973. The geochemistry of iodine in oxidised and 637 reduced recent marine sediments. Geochim. Cosmochim. Acta 37, $638 \quad 2149-2158$.

639 Ramos, E.G., 2002. Origin and geologic features of Taal Lake, Philippines. 640 Aquat. Ecosyst. Health Manag. 5, 155-162.

641 Reithmeier, H., Lazarev, V., Rühm, W., Nolte, E., 2010. Anthropogenic ${ }^{129}$ I in 642 the atmosphere: Overview over major sources, transport processes and deposition pattern. Sci. Total Environ. 408, 5052-5064.

Reithmeier, H., Lazarev, V., Ruhm, W., Schwikowski, M., Gaggeler, H.W., 645 Nolte, E., 2006. Estimate of European ${ }^{129}$ I releases supported by ${ }^{129} \mathrm{I}$ analysis in an alpine ice core. Environ. Sci. Technol. 40, 5891-5896.

Ribbe, J., Tomczak, M., 2006. An impact assessment for the French Nuclear Weapon Test Sites in French Polynesia. Mar. Pollut. Bull. 21, 536-542.

Santos, F.J., López-Gutiérrez, J.M., García-León, M., Synal, H.A., San Miguel, E.G., 2007. ${ }^{129}$ I record in a sediment core from Tinto River (Spain). Nucl.

652 Shinohara, K., 2004. Measurement and behavior of ${ }^{14} \mathrm{C}$ and ${ }^{129} \mathrm{I}$ in the environment. J. Radioanal. Nucl. Chem. 260, 265-271. 
657 Stuiver, M., Polach, H.A. 1977. Discussion: reporting of ${ }^{14} \mathrm{C}$ data. Radiocarbon $658 \quad 19,355-363$.

659 Suzuki, T., Minakawa, M., Amano, H., Togawa, O., 2010. The vertical profiles 660 of iodine-129 in the Pacific Ocean and the Japan Sea before the routine 661 operation of a new nuclear fuel reprocessing plant. Nucl. Instrum. Meth. B 662 268, 1229-1231.

663 Toyama, C., Muramatsu, Y., Igarashi, Y., Aoyama, M., Matsuzaki, H., 2013. 664 665 666 Atmospheric fallout of ${ }^{129} \mathrm{I}$ in Japan before the Fukushima accident: Regional and global contributions (1963-2005). Environ. Sci. Technol. 47, 8383-8390.

667 Ullman, W.J., Aller, R.C., 1980. Dissolved iodine flux from estuarine sediments 668 and implications for the enrichment of iodine at the sediment water interface. 669 Geochim. Cosmochim. Acta 44, 1177-1184.

670 UNSCEAR, 2000. Sources, effects and risk of ionizing radiation, UNSCEAR 671 Report to the General Asembly.

672 Villafuerte, M.Q., Matsumoto, J., Akasaka, I., Takahashi, H.G., Kubota, H., 673 Cinco, T.A., 2014. Long-term trends and variability of rainfall extremes in 674 the Philippines. Atmos. Res. 137, 1-13.

675 World Nuclear Association, 2017. http://www.world-nuclear.org/. Last access 9 676 Jan 2017. 
677 Xing, S., Hou, X., Aldahan, A., Possnert, G., Shi, K., Yi, P., Zhou, W., 2015. 678 Iodine-129 in snow and seawater in the Antarctic: level and source. Environ. Sci. Technol. 49, 6691-6700.

680

681

682

683

684

685

686

687

688

689

690

691

692

693

694

695

696

Xu, Z.K., Li, T.G., Yu, X.K., Li, A.C., Tang, Z., Choi, J.Y., Nan, Q.Y., 2013. Sediment provenance and evolution of the East Asian winter monsoon since 700 ka recorded by major elements in the West Philippine Sea. Chinese Sci. Bull. 58, 1044-1052.

Yiou, F., Raisbeck, G.M., Christensen, G.C., Holm, E., 2002. ${ }^{129} \mathrm{I} /{ }^{127} \mathrm{I},{ }^{129} \mathrm{I} /{ }^{137} \mathrm{Cs}$ and ${ }^{129} \mathrm{I} /{ }^{99} \mathrm{Tc}$ in the Norwegian coastal current from 1980 to 1998. J. Environ. Radioactiv. 60, 61-71.

Zhang, L., Hou, X., Xu, S., 2016. Speciation of ${ }^{127} \mathrm{I}$ and ${ }^{129} \mathrm{I}$ in atmospheric aerosols at Ris $\varnothing$, Denmark: Insight into sources of iodine isotopes and their species transformations. Atmos. Chem. Phys. 16, 1971-1985.

Zhang, L., Zhou, W.J., Hou, X., Chen, N., Liu, Q., He, C., Fan, Y., Luo, M., Wang, Z., Fu, Y., 2011. Level and source of I-129 of environmental samples in Xi'an region, China. Sci. Total Environ. 409, 3780-3788.

Zhou, W.J., Hou, X., Chen, N., Zhang, L.Y., Liu, Q., He, C.H., Luo, M.Y., Liang, W.G., Fan, Y.K., Wang, Z.W., Fu, Y.C., Li, H.B., 2010. Preliminary study of radioisotope ${ }^{129} \mathrm{I}$ application in China using Xi'an accelerator mass spectrometer. ICNS News 25, 8-23. 


\section{Caption of figures}

Fig. 1 Locations of Taal Lake in the central Philippines (red diamond), nuclear power plants (blue circles), nuclear fuel reprocessing plants in United Kingdom, France and Japan (green triangles), major bomb testing sites in the Pacific Ocean (hollow squares) and other sampling sites for corals from Parala and Baler, and precipitation from Ishigaka (black dots). The insert shows the locations of two nuclear fuel reprocessing plants, Sellafield and La Hague in Europe. The prevailing winds are westerly (light blue arrow) at mid-high latitudes and equator trade winds (light purple arrow). Regional winds are the East Asia Monsoon in winter (aqua dash-line arrows), summer (orange dot-line arrows), and northeasterly trade winds (red dash dot arrows). Ocean currents in the South China Sea during winter are denoted by black line arrows.

Fig. 2 Concentrations of ${ }^{127} \mathrm{I}$ and ${ }^{129} \mathrm{I}$ and the ratios of ${ }^{129} \mathrm{I} /{ }^{127} \mathrm{I}$ in the Taal Lake sediment core. The peaks of ${ }^{127} \mathrm{I}$ and ${ }^{129} \mathrm{I}$ concentrations occur at the depth of $7.1 \mathrm{~cm}$ (orange band). Events of volcanic eruptions during 1965-1977 are shown as blue bands.

Fig. 3 (a) ${ }^{129} \mathrm{I} /{ }^{127} \mathrm{I}$ ratios and $\Delta^{14} \mathrm{C}$ in the sediment core from Taal Lake, Philippines and (b) comparison to ${ }^{129} \mathrm{I} /{ }^{127} \mathrm{I}$ ratios of Jiaozhou Bay, China (Fan et al., 2016), and coral from Parola, Philippines from the South China Sea side and Baler, the Philippines at the west Pacific Ocean side 
(Bautista et al., 2016). (c) ${ }^{129} \mathrm{I}$ releases (GBq) from atmospheric NWT, NFRPs, the Chernobyl accident and re-emission from contaminated oceans (compiled from Fan et al., 2016 and Bautista et al., 2016). The highest peak of ${ }^{129} \mathrm{I} /{ }^{127} \mathrm{I}$ ratios around 1984 appears to be the signal of the Chernobyl accident in 1986 . The lesser peaks (1, 2 and 3) correspond well the releases of ${ }^{129}$ I from the two European NFRPs in 1989, 1994 and 1996, respectively. The fourth peak might be related to the stronger East Asia wither monsoon in 2004. 


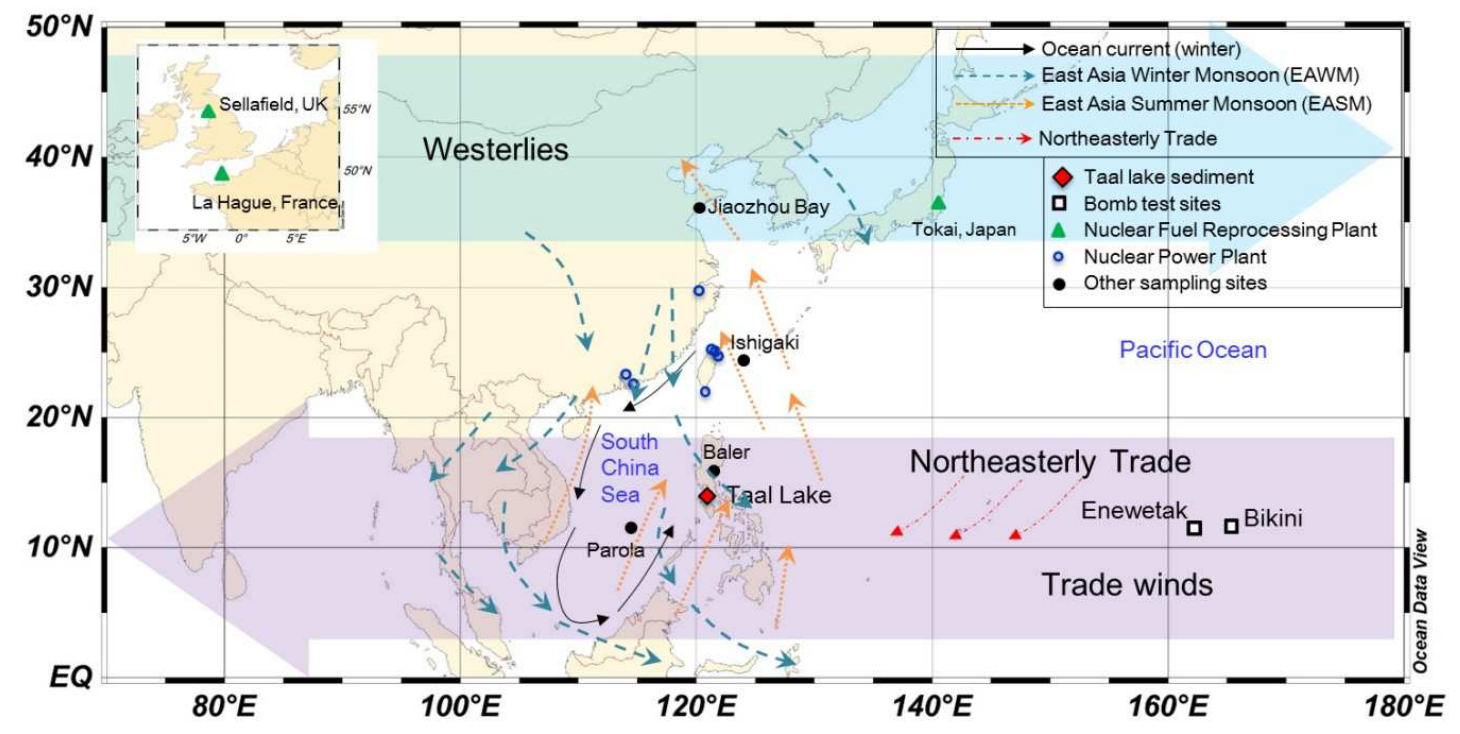




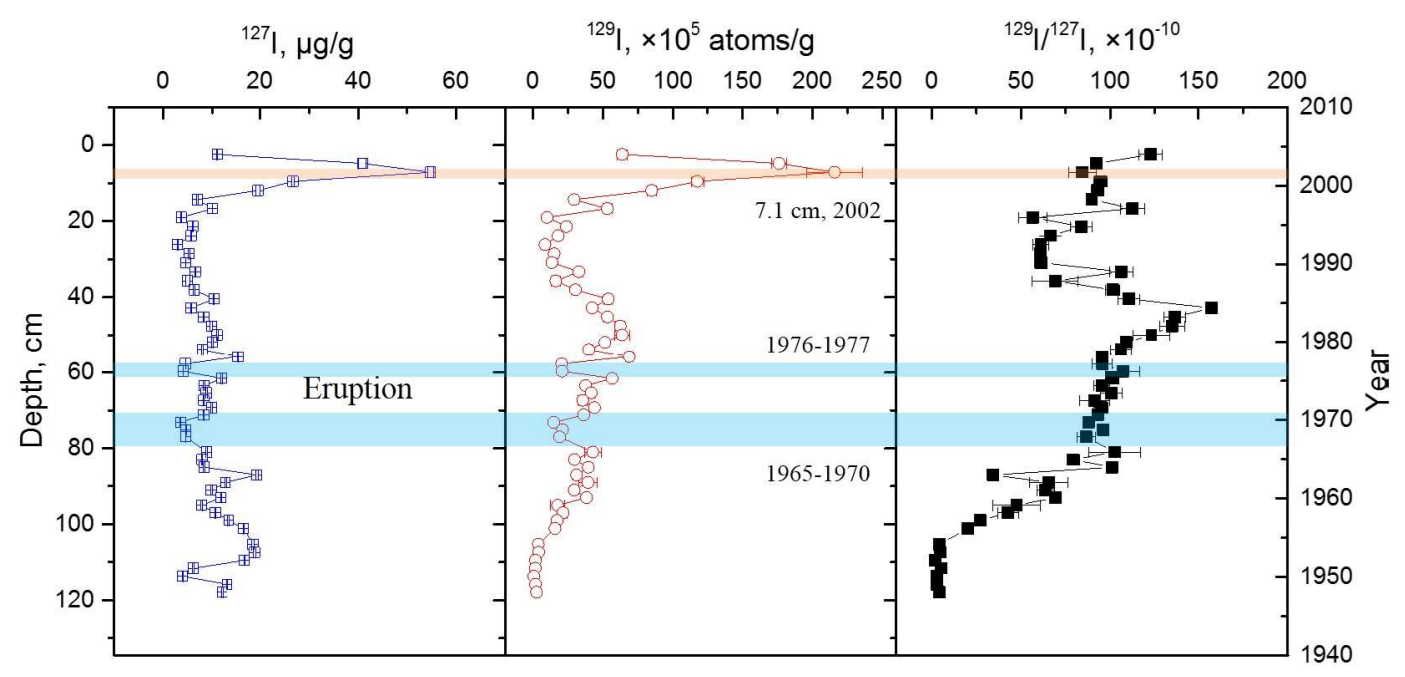




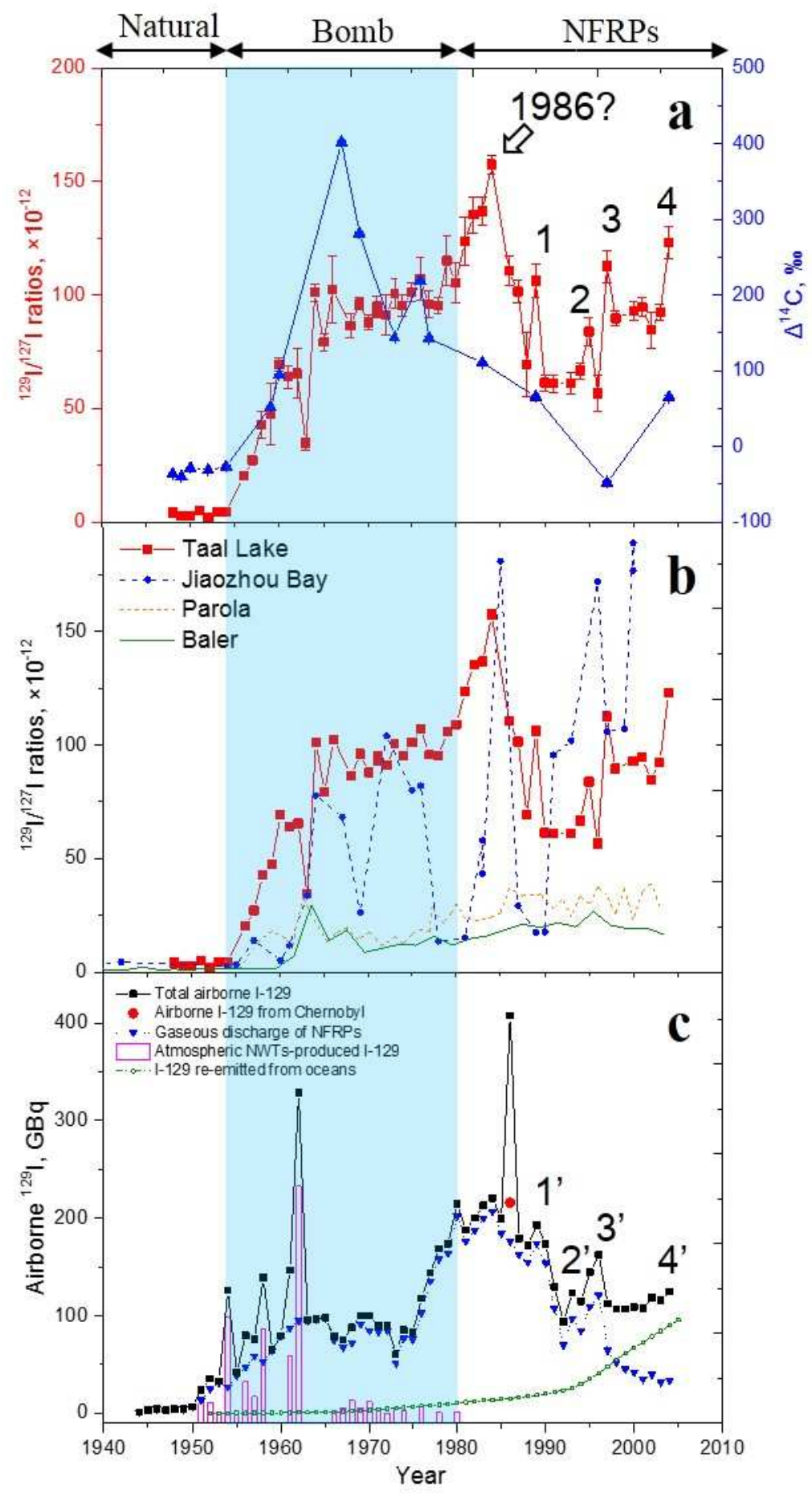




\section{- Highlights}

The highlights of this paper involve:

i. A 60-year ${ }^{129}$ I profile in Taal Lake sediment is reported.

ii. Human nuclear activities at low latitudes are well recorded by ${ }^{129} \mathrm{I}$ profile;

iii. Northeasterly trade and East Asian winter monsoon are important driving forces;

iv. Iodine isotopes are potentially applied as a tracer for volcanic eruptions; 